\title{
Path Coefficient Analysis of Seed Yield in Big Bluestem
}

\author{
A. BOE AND J.G. ROSS
}

\begin{abstract}
Path coefricient analysis was performed on 19 spaced-plant, open-pollinated big bluestem (Andropogon gerardit Vit.) progenies to determine direct and indirect effects of seed yield components (number of flowering culms, florets per culm, fertility index, and seed weight) on seed yield. Seed yield was positively correlated with all its components. Number of fowering culms, florets per culm, and fertility index had substantial direct effects, in that order, on seed yield. The significant positive total correlation between seed weight and seed yield resulted from positive indirect effects of norets per culm and fertility index. The negative indirect effect of number of flowering culms substantially reduced total correlations between seed yield and fertility index and florets per culm. Correlations between forage characters and number of flowering culms and seed yield were highly significant. Number of flowering culms was negatively correlated with seed weight, fertility index, and noret per culm.
\end{abstract}

Any range grass breeding program needs to emphasize improvement of seed characters, especially size and yield. One factor that has limited the success of big bluestem (Andropogon gerardii Vit.) in planted pastures and revegetation programs is low yield of quality seed. A wide range of seed yield variation exists in many of the native range grasses, and a knowledge of the interrelationships of seed yield components (e.g., seed weight, fertility, and flowering culm production) is necessary if improvement for these traits is to be made.

This study was conducted to obtain information on the nature of seed yield component relationships in big bluestem.

\section{Materials and Methods}

Open-pollinated progenies of 19 big bluestem plants were planted in a spaced-plant nursery in 1977 at Brookings, S. Dak. Each progeny was represented in 3 replicates by a 10 -plant plot.

\footnotetext{
Authors are assistant professor and professor of plant science, South Dakota State University, Brookings 57007

This report is a contribution from the South Dakota State University Agricultural Experiment Station, Brookings 57007 . This is part of a thesis by the senior author in partial fulfillment of the requirements for the Ph.D. degree at South Dakota State University. Journal Paper No. 1763.

Manuscript received March 8, 1982.
}

The parent plants were progenies of relict populations from extreme eastern South Dakota. During the fall of 1978, 323 plants ( 7 from each progeny in the first replicate and 5 from each progeny in the other replicates) were harvested for seed and the following observations were made: (1) seed yield (total weight of fertile spikelets), (2) number of flowering culms, (3) florets per culm (estimated by weight of unthreshed racemes/number of culms), (4) fertility index (percent fertile florets estimated by seed yield/total weight of unthreshed racemes (Raeber and Kalton 1956)), (5) weight of 100 naked caryopses, (6) vigor (scale was $5=$ most vigorous to $1=$ least vigorous), $(7)$ leafiness (scale was $5=$ leafiest to $1=$ least leafy), and (8) plant height. Individual plant seed characters were subjected to maximum $r^{2}$ multiple regression analysis. Path coefficients were computed from partial regression coefficients and standard deviations of the dependent and independent variables ( $\mathrm{Li} \mathrm{1975)}$. Seed yield was considered the dependent variable and components of seed yield (observations 2-5) were considered independent variables.

Path coefficients measure the direct influence of one variable upon another and permit the separation of the correlation coefficient into components of direct and indirect effects.

\section{Results and Discussion}

Positive associations existed between seed yield and all its components, with number of flowering culms having the largest correlation $(r=0.54, P<0.01)$ (Table 1). However, number of flowering culms was negatively associated with the other components, suggesting seed yield component compensation (Adams 1967). Plants that produced many culms generally produced fewer florets per culm, smaller seeds, and were less fertile than plants producing few culms. Dewey and Lu (1959) reported mature plant weight was positively correlated with seed yield in crested wheatgrass (Agropyron cristatum L.), indicating the seed-producing advantage of large plants came from more spikes per plant.

Seed weight, as shown in Table 1, was positively correlated with fertility index $(r=0.38, P<0.01)$ and florets per culm $(r=0.23$ $P<0.01$ ). This is contrary to findings of Dewey and Lu (1959), but Christie and Kalton (1960) and Massey (1964) found positive 
Table 1. Correlation coefincients for forage and seed characters.

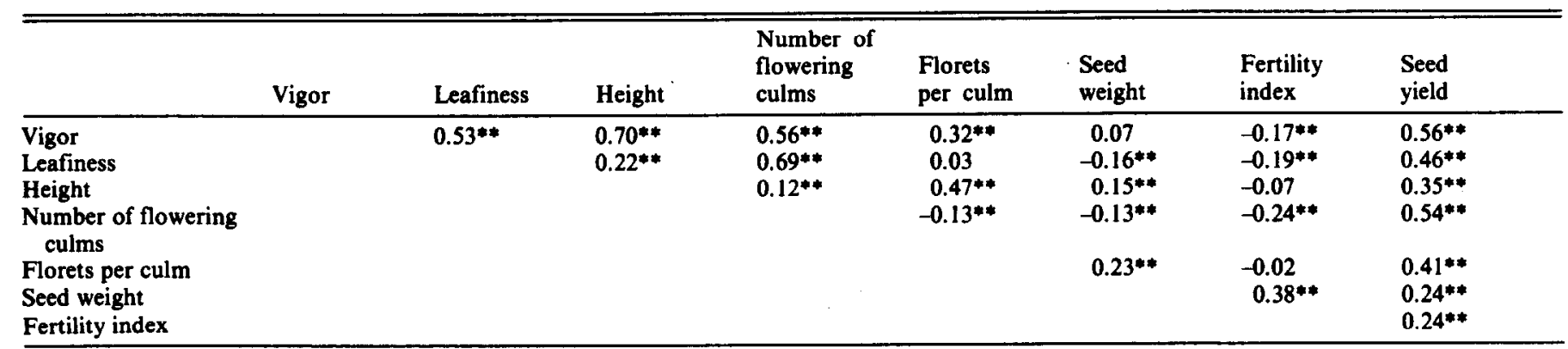

* Significant at the $1 \%$ probability level.

correlations between fertility index and seed weight in smooth bromegrass (Bromus inermis Leyss.), and seed weight and seed set in big bluestem, respectively.

Path analysis pointed out that number of flowering culms, florets per culm, and fertility index had strong direct effects, in that order, on enhancement of seed yield (Table 2). Seed weight, however, contributed to seed yield largely through indirect effects of florets per culm and fertility index.

Table 2. Path coeficient analysis of number of culms, seed weight, fertility Index, and florets per culm upon seed yield.

\begin{tabular}{lr}
\hline \hline Pathways of association & Coefficients \\
\hline Seed yield vs. number of flowering culm & \\
Direct effect & 0.756 \\
Indirect effect via florets/culm & -0.105 \\
Indirect effect via fertility index & -0.105 \\
Indirect effect via seed weight & -0.003 \\
Total correlation & 0.542 \\
Seed yield vs. florets/culm & \\
Direct effect & 0.574 \\
Indirect effect via number of flowering culms & -0.139 \\
Indirect effect via fertility index & -0.031 \\
Indirect effect via seed weight & 0.007 \\
Total correlation & 0.410 \\
Seed yield vs. fertility index & \\
Direct effect & 0.447 \\
Indirect effect via number of flowering culms & -0.178 \\
Indirect effect via florets/culm & -0.040 \\
Indirect effect via seed weight & 0.012 \\
Total correlation & 0.241 \\
Seed yield vs. seed weight & \\
Direct effect & \\
Indirect effect via number of flowering culms & -0.087 \\
Indirect effect via florets/culm & 0.127 \\
Indirect effect via fertility index & 0.178 \\
Total correlation & 0.247 \\
\hline
\end{tabular}

Correlations between seed yield and florets per culm and fertility index would have been high had it not been for the large negative indirect effect of number of flowering culms. Conversely, the correlation between number of flowering culms and seed yield was reduced by negative indirect effects of fertility index and florets per culm.

The usefulness of path analysis can be exemplified by a particular relationship. The total correlation between seed yield and seed weight was positive and highly significant $(r=0.24, P<0.01)$. This suggests that increasing seed weight would have a positive effect on seed yield. However, when florets per culm and fertility index were held constant, seed weight had essentially no effect on seed yield (path coefficient between seed weight and seed yield $=0.03$ ) (Table 2). The indirect effects were more important and masked the direct relationship.
In total, $76 \%$ of the variation in seed yield could be explained by variation in the 4 independent variables (Table 3 ). The unexplained variation, $24 \%$ of the total, may be due in part to variation in pubescence of inflorescence structures, as it hindered threshing efficiency.

\section{Table 3. Summary of stepwise multiple regression analysis of seed yield and seed yield components.}

\begin{tabular}{lc}
\hline \hline Regression equations 1 & $\begin{array}{c}\text { Coefficient of } \\
\text { determination }\end{array}$ \\
\hline $\mathrm{SY}=1.22+0.18 \mathrm{FC}$ & 0.294 \\
$\mathrm{SY}=-3.39+0.21 \mathrm{FC}+6.00 \mathrm{~F} / \mathrm{C}$ & 0.563 \\
$\mathrm{SY}=-9.29+0.25 \mathrm{FC}+6.62 \mathrm{~F} / \mathrm{C}+0.11 \mathrm{FI}$ & 0.759 \\
$\mathrm{SY}=-9.66+0.25 \mathrm{FC}+6.53 \mathrm{~F} / \mathrm{C}+0.11 \mathrm{FI}+3.08 \mathrm{SW}$ & 0.760 \\
\hline
\end{tabular}

ISY = seed yield, FC = number of flowering culms, F/C = florets $/$ culm, FI = fertility index, and $\mathrm{SW}=100$ seed weight.

The data obtained from this study should be useful to range grass breeders and seed producers concerned with increasing seed yields. Since many-culmed plants generally produced large seed yields, but exhibited low seed set and light seed weight, strict selection for culm numbers could have adverse effects on seed size and fertility. Seed size is an important character influencing stand establishment of big bluestem (Boe 1979) and should not be ignored in favor of flowering culm numbers. However, the negative relationship between seed weight and number of flowering culms is not formidable, and simultaneous selection for both should be attempted. This is particularly important since number of flowering culms is positively correlated with forage value and yield, as measured by vigor, leafiness, and height (Table 1). It should be possible to develop high forage yielding populations that also produce substantial amounts of high quality seed.

\section{Literature Cited}

Adams, W.M. 1967. Basis of yield component compensation in crop plants with special reference to the field bean, Phaseolus vulgaris. Crop Sci. 7:505-510.

Boe, A. 1979. Variability and breeding behavior in big bluestem populations from eastern South Dakota. Ph.D. Thesis. S. Dakota State Univ., Brookings.

Christie, B.R., and R.R. Kalton. 1960. Inheritance of seed weight and associated traits in bromegrass, Bromus inermis Leyss. Can. J. Pl. Sci. 40:353-365.

Dewey, D.R., and K.H. Lu. 1959. A correlation and path coefficient analysis of components of crested wheatgrass seed production. Agron. J. 51:515-518.

Li, C.C. 1975. Path analysis: A primer. Boxwood Press. Pacific Grove, Calif.

Massey, G.D. 1964. Seed characteristics and seedling behavior in three bluestem species. Diss. Abst. 25:3179-3180.

Raeber, J.G., and R.R. Kalton. 1956. Variation and inheritance of fertility and its components in Bromus inermis Leyss. Agron. J. 48:212-216. 